\title{
Cytological Diagnosis of Body Fluids and Fine Needle Aspirates-Correlation between Cytospin Method and Cell Block Preparation, at a Tertiary Centre
}

\author{
Dr. Urvi Dobaria ${ }^{1}$, Dr. Gauravi Dhruva ${ }^{2}$ \\ ${ }^{1} 3^{\text {rd }}$ year Postgraduate Student, PDU Medical College \& Hospital, Rajkot, India \\ ${ }^{2}$ MD Pathology, Professor \& Head of Dept, PDU Medical College \& Hospital, Rajkot, India
}

\begin{abstract}
Diagnostic cytology is a science based on three basic sampling techniques:- Collection of exfoliated cells; Collection of cells removed by brushing or similar abrasive technique; Aspiration biopsy or removal of cells from non - surface bearing tissues by means of needle with or without a syringe. Method: Patients were diagnosed by clinical history, lab tests, \& cytological examination by cytocentrifuge and cell block technique as and when required. Fixative was usually not added because ethanol the usual cytological fixative causes heavy precipitation of proteins which interferes with concentration of cells. Conclusion: It is thus concluded from the present study that it is advisable to study by both cytospin and cell block method before discarding specimens that are negative for malignant cells by smear examination.
\end{abstract}

Keywords: Cytospin smear, Cell block preparation, Body fluids, Fine needle aspirates

\section{Introduction}

History of diagnostic cytopathology began in $1^{\text {st }}$ era- $19^{\text {th }}$ century. The second and most important era began in 1941 with the publication by Dr. George N. Papanicolaou (father of cytology) of an article in the American journal of obstetrics and Gynecology: The diagnostic value of vaginal smears in carcinoma of the uterus.

Diagnostic cytology is a science based on three basic sampling techniques: Collection of exfoliated cells; Collection of cells removed by brushing or similar abrasive technique; Aspiration biopsy or removal of cells from non surface bearing tissues by means of needle with or without a syringe.

Exfoliative cytology: Exfoliative cytology is based on spontaneous shedding of cells derived from the lining of an organ into a cavity, where they can be removed by nonabrasive means. Typical examples being vaginal smear prepared from cells removed from posterior fornix of the vagina and sputum. The principles of exfoliative cytology also apply to the body cavity effusions where collection of fluid is made by pleural, peritoneal or pericardial tapping. The principle lesions that can be identified are metastatic cancer and primary mesotheliomas. Apart from the routine cytomorphological study, tumour marker, Immunocytochemistry scanning electron microscopy etc. can be used to aid in diagnosis. ${ }^{1}$

Aspiration cytology: Fine needle aspiration cytology (FNAC) was introduced with a view to reduce the number of excisional biopsies of lymph nodes. Needle aspiration of lymph nodes was used at the beginning of the $20^{\text {th }}$ century to identify parasites in sleeping sickness, secondary syphilis, filariasis and bubonic plague. FNAC is a simple, minimally invasive and rapid diagnostic technique. It is safe, reliable, cost effective outpatient department procedure which avoids morbidity and psychological trauma. Various studies supported the use of FNA as a primary method of diagnosis in reactive, infective and metastatic lymphadenopathy and also to know the primary site of malignancy. Definitive diagnosis can be made in most cases, thus sparing more expensive radiological investigations and/or surgical intervention.

\section{Materials and Method}

Materials needed for processing:

Disposable needled of 22-24 G with length of $2.5-3.8 \mathrm{~cm}$; Disposable plastic syringes of 10-20cc; Glass slides-clean and grease free; Methanol as fixative; Reagents for H\&E stain, PAP stain; Sterile gloves, gauze piece and spirit swab.

\section{Method for processing:}

An effusion of serous cavity is diagnosed by correlating clinical \& laboratory methods to differentiate Benign \& Malignant effusions. The present study is from indoor patients of Government Hospital. Patients were diagnosed by clinical history, lab tests, \& cytological examination by cytocentrifuge and cell block technique as and when required. Fixative was usually not added because ethanol the usual cytological fixative causes heavy precipitation of proteins which interferes with concentration of cells. Freshly tapped specimens are preferred for cytology, if facilities for immediate processing are available; if such facilities are not available, it can be preserved in refrigerator for 24-48 hours.

\section{Cytological examination}

Routine smear processing. Fluid received was stirred briskly to concentrate the suspended cells. The representative volume of fluid is centrifuged at $2500 \mathrm{rpm}$ for 5 minutes. Smears were prepared from sediment on to glass slide by a 


\section{International Journal of Science and Research (IJSR) \\ ISSN (Online): 2319-7064}

Index Copernicus Value (2015): 78.96 | Impact Factor (2015): 6.391

thin cotton swab applicator stick \& immediately fixed in $95 \%$ ethanol.

a) Cell block preparation: Plasma Thromboplastin Cell Block technique was used.

b) Cytocentrifugation: Cytospin method was used with routine smear.

In present study, slides were stained by H\&E stain. Various Cytomorphological criteria were used for diagnosis \& typing of neoplasm \& for determining primary site of the tumors.

\section{Discussion}

In the present study, routine and cytological examination of ascitic and pleural fluid and various aspirates was carried out to differentiate between malignant and non malignant effusions. Total 80 cases of ascitic and pleural fluid and aspirates were studied by routine examination and cytological examination. The results obtained were compared with other authors, who have worked previously in this field on routine and cytological examination of fluids and the significant difference and similarities in results are discussed follows.Cordozo ${ }^{2}$ (1966) used an anticoagulant in his study and added either heparin or EDTA to every fresh fluid specimen. Malvi and $\operatorname{Anthony}^{3}(2000)$ studied the various methods of processing hemorrhagic serous fluid. In the present study, freshly tapped specimens without addition of anticoagulant were used for preparing smears and in cases where delay was inevitable, specimens were refrigerated. Spieler and Friedrich ${ }^{4}$ (1985), Di Bonito et al $^{5}$ (1992), Sears and Hadju $^{6}$ (1987) had used alcohol fixed smears in their study while Cordozo ${ }^{2}$ (1966) and Johnson ${ }^{7}$ (1966) has used air dried smears in their study. In the present study ether alcohol (v/v) fixed smears were used. Konikov et $\mathrm{al}^{8}$ (1966) and Broghamer et $\mathrm{al}^{9}$ (1984) had used Hand E stained cell block technique.

Table 1

\begin{tabular}{|c|c|c|c|c|}
\hline SAMPLE & Pleural fluid & Peritoneal fluid & Aspirates & Hydrocolpos \\
\hline
\end{tabular}

\begin{tabular}{|c|c|c|c|c|}
\hline No of cases & 56 & 07 & 19 & 01 \\
\hline
\end{tabular}

Table 2

\begin{tabular}{|c|c|c|c|}
\hline Sr. No. & $\begin{array}{c}\text { Gender of } \\
\text { the patient }\end{array}$ & $\begin{array}{c}\text { No. of cases of } \\
\text { Pleural fluid }\end{array}$ & $\begin{array}{c}\text { No. of cases of } \\
\text { Ascitic fluid }\end{array}$ \\
\hline 1. & Male & 35 & 3 \\
\hline 2. & Female & 21 & 4 \\
\hline & Total & 56 & 7 \\
\hline
\end{tabular}

Table 3

\begin{tabular}{|c|c|c|c|c|}
\hline $\begin{array}{c}\text { Exfoliative } \\
\text { Cytology }\end{array}$ & Inflammatory & $\begin{array}{c}\text { Reactive } \\
\text { Mesothelial } \\
\text { Cells }\end{array}$ & $\begin{array}{c}\text { Malignant } \\
\text { Effusion }\end{array}$ & $\begin{array}{c}\text { No Cellular } \\
\text { Details }\end{array}$ \\
\hline No. of cases & 49 & 06 & 10 & 01 \\
\hline
\end{tabular}

Table 4

EXFOLIATIVE

\begin{tabular}{|c|c|c|c|}
\cline { 2 - 4 } \multicolumn{1}{c|}{} & \multicolumn{2}{c|}{ EXFOLIATIVE } & \multicolumn{1}{c|}{$\begin{array}{c}\text { No Cellular } \\
\text { Details }\end{array}$} \\
\hline $\begin{array}{c}\text { An years }) \\
1-10\end{array}$ & Inflammatory & $\begin{array}{c}\text { Reactive Mesothelial } \\
\text { Cells }\end{array}$ & - \\
\hline $11-20$ & 03 & - & - \\
\hline $21-30$ & 03 & 01 & - \\
\hline $31-40$ & 05 & - & - \\
\hline
\end{tabular}

\begin{tabular}{|c|c|c|c|}
\hline $41-50$ & 17 & - & 01 \\
\hline $51-60$ & 13 & 03 & - \\
\hline$>60$ & 05 & - & - \\
\hline
\end{tabular}

Table 5

\begin{tabular}{l} 
Table 5 \\
\cline { 2 - 2 } \\
\begin{tabular}{|c|c|}
\hline \multicolumn{1}{c|}{} \\
\hline AGE ( in years ) & Exfoliative \\
\hline $1-10$ & Malignant \\
\hline $11-20$ & - \\
\hline $21-30$ & - \\
\hline $31-40$ & - \\
\hline $41-50$ & 01 \\
\hline $51-60$ & - \\
\hline$>60$ & 07 \\
\hline & 02 \\
\hline
\end{tabular}
\end{tabular}

Table 6

\begin{tabular}{|c|c|c|c|c|c|}
\cline { 2 - 4 } \multicolumn{1}{c|}{} & \multicolumn{3}{c|}{ Aspiration Cytology } & \multicolumn{1}{c}{} \\
\hline $\begin{array}{c}\text { Age } \\
\text { (in } \\
\text { years ) }\end{array}$ & Cystic & $\begin{array}{c}\text { Infllam- } \\
\text { matory }\end{array}$ & $\begin{array}{c}\text { Inflammatory } \\
\text { Cystic }\end{array}$ & Abscess & Hydroclpos \\
\hline $1-10$ & - & - & - & - & - \\
\hline $11-20$ & - & - & - & 01 & 01 \\
\hline $21-30$ & 01 & - & - & - & - \\
\hline $31-40$ & - & - & - & - & - \\
\hline $41-50$ & 01 & 01 & 01 & 01 & - \\
\hline $51-60$ & - & - & 02 & - & - \\
\hline$>60$ & - & - & 01 & - & - \\
\hline
\end{tabular}

Table 7

\begin{tabular}{|c|c|}
\cline { 2 - 2 } \multicolumn{1}{c|}{} & Aspiration Cytology \\
\hline Age (in years ) & Malignant \\
\hline $1-10$ & - \\
\hline $11-20$ & - \\
\hline $21-30$ & - \\
\hline $31-40$ & - \\
\hline $41-50$ & - \\
\hline $51-60$ & 03 \\
\hline$>60$ & 03 \\
\hline
\end{tabular}

\section{Comparative Study of Cytospin and Cell Block Technique}

Only few studies have been reported regarding utility of cell block and cytospin methods in a case of diagnostic dilemma in a cytological smear.

Liu $\mathrm{K}^{10}(1998)$ compared the results of smears to those of cytospin and cell block preparations to determine which should be routinely obtained. Cytospin smear alone diagnostic in $100 \%$ of cases, and cell blocks alone diagnostic in $100 \%$ of cases. Cell blocks contributed no additional information beyond that obtained from cytospin smears.

In present study, out of 10 cases of malignancy, all 10 cases were detected by both cytospin smears and cell block methods.

\section{Conclusion}

Routine examination and cytological examination of effusions has an important diagnostic value to find out the cause of the effusion. There are many non invasive tests available which are relatively very simple, easy to perform, less time consuming and repeatable. Routine examination can help in differentiation of transudative and exudative 


\section{International Journal of Science and Research (IJSR) \\ ISSN (Online): 2319-7064 \\ Index Copernicus Value (2015): 78.96 | Impact Factor (2015): 6.391}

fluids and cytological examination with smear, cytospin, cell block technique of fluid sediment and some special histochemical stains are helpful in the diagnosis and typing of malignancy in effusion. It is recommended that cytospin, cell blocks and routine smears should be used in evaluating all fluids submitted to the cytology laboratory. Knowledge of cytology of body fluids is of great help to the patients having inoperable malignancies where palliative treatment is at need. It also obviates the need of unnecessary surgery.

Cell blocks have helped in increasing the diagnostic yield can be used for the recognition of histological patterns of the disease, and for various ancillary studies that would not be possible with routine cytological examination and cytospin technique.

The other proved advantages of Cell Block method are:
- Preservation of tissue architecture and obtaining multiple sections for special stains.

- Recognition of Histological patterns of diseases that sometimes may not be identified in conventional smears.

- Less cellular dispersal, this permits easy microscopic observation.

- Storage of slides for retrospective studies.

- Use of blocks for advanced investigations like Immunostaining \& Immunohistochemistry.

It is thus concluded from the present study that it is advisable to study by both cytospin and cell block method before discarding specimens that are negative for malignant cells by smear examination.

Following are the figures for comparison between cytospin smears and cell block sections:-

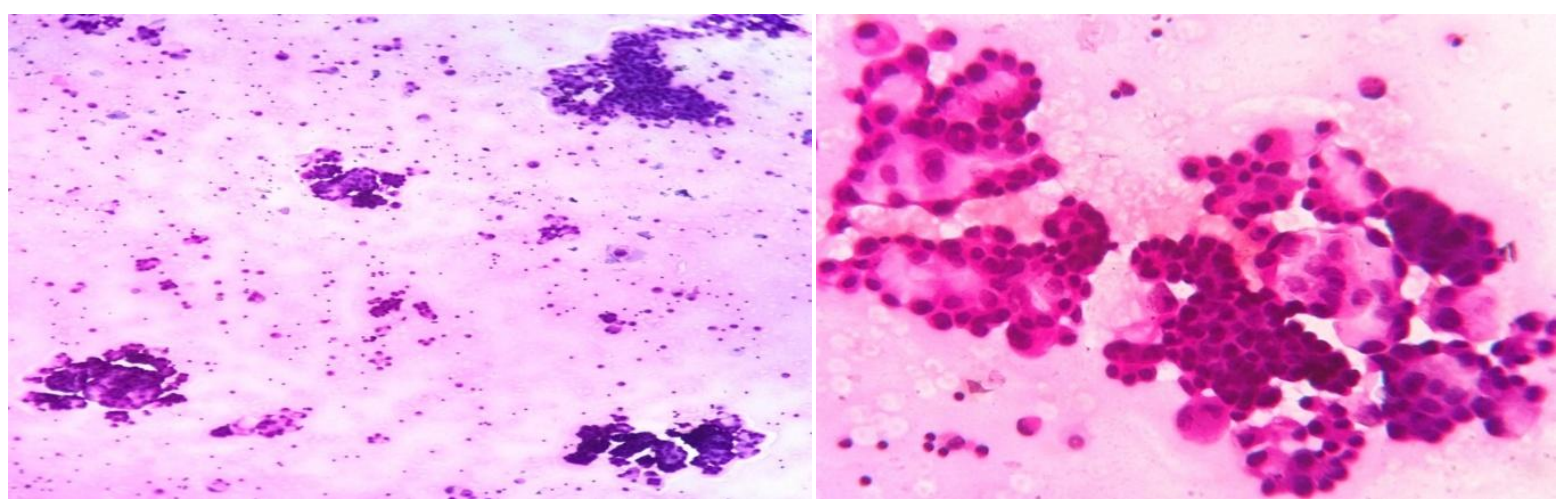

Figure 1: Reactive Mesothelial cells, 10X view and 40X view, H\&E stain.
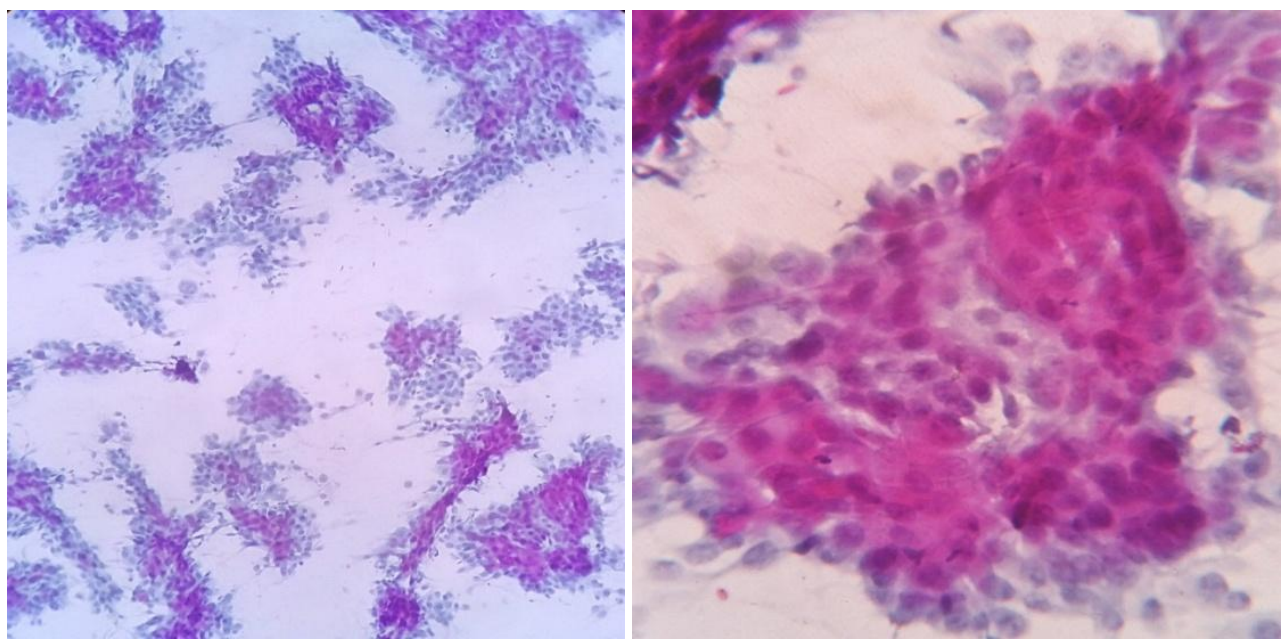

Figure 2: Metastatic Squamous Cell Carcinoma- 10X view, and 40X view, respectively, PAP stain 
International Journal of Science and Research (IJSR)

ISSN (Online): 2319-7064

Index Copernicus Value (2015): 78.96 | Impact Factor (2015): 6.391

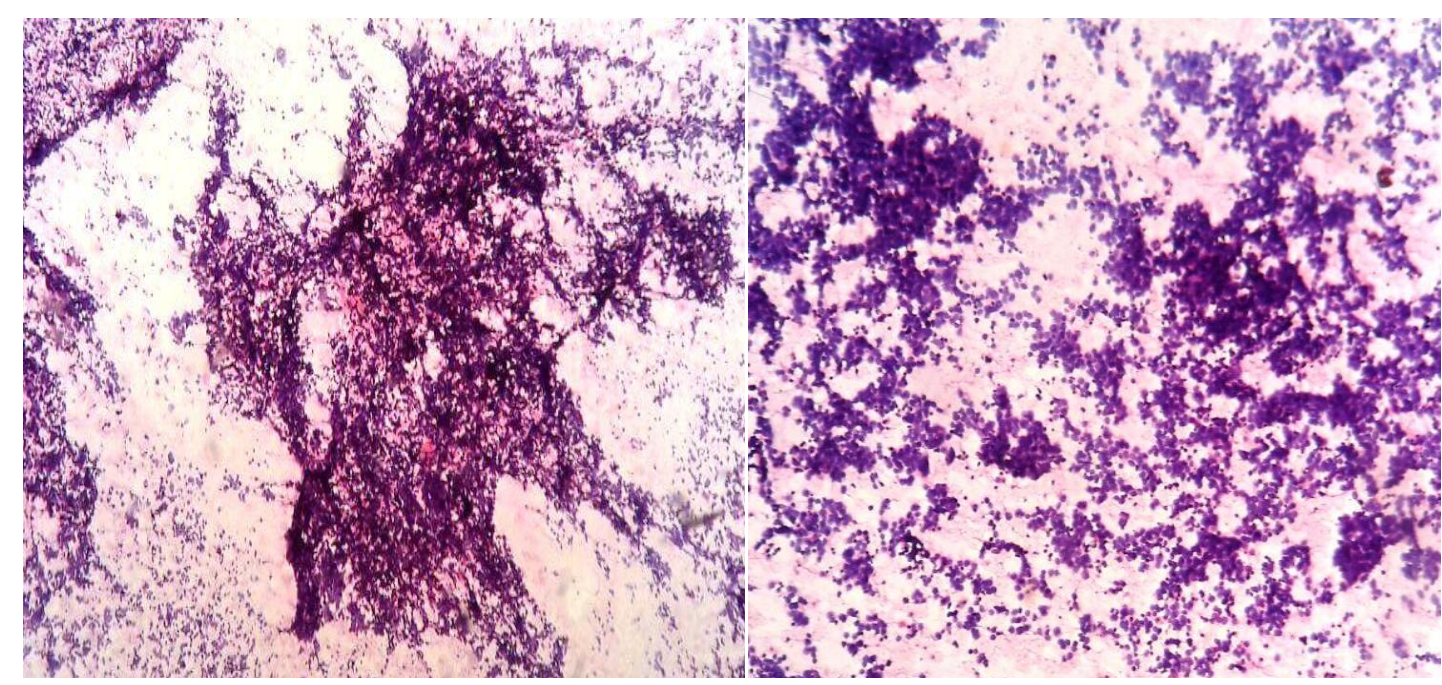

Figure 3: Metastatic Small Cell Carcinoma- 10X view, H\&E Stain.
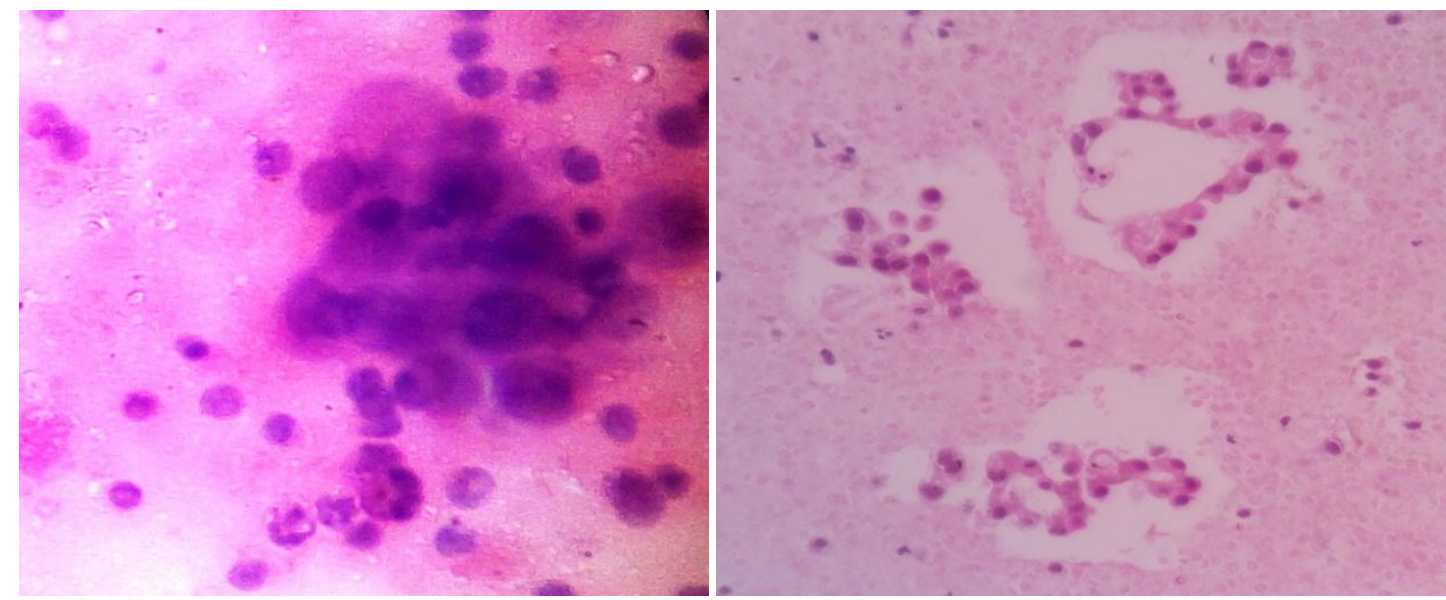

Figure 4: Metastatic Adenocarcinoma- 40X view, H\&E Stain

\section{References}

[1] Koss LG, Myron R. Melamed; Koss's diagnostics cytology and its histopathologic bases, vol-1, 2,5th edition, Lippincott company, Philadelphia, USA.pg:919-1016.

[2] Cordozo PL; A critical evaluation of 3000 cytologic analysis of pleural fluid, ascitic fluid and pericardial fluid; Acta cytology: 10(6): 455-460,Nov.1966.

[3] Bourgoyre JR: Theories of cancer etiology, oral cancer,pg:9-34.

[4] Spiewler peter and Friedrich Gloor; identification of types and primary sites of malignant tumours by examination of exfoliated tumour cells in serous effusion; Acta cytology 29 (5) Oct-1985: 753-767.

[5] DiBonito Luigi, Falconieri G, Colauth I, Bonitacio D; The positive pleural effusion; A retrospective study of cytological diagnosis with autopsy confirmation, Acta cytology 36(2):1992;329-332.

[6] Sears D, Hadju SI; The cytologic diagnosis of malignant neoplasms in pleural and peritoneal effusions, Acta cytology 3:1987; 85-97.

[7] Johnson William D; The cytological diagnosis of cancer in serous effusion, Acta cytology-10 (3) ; 161-171,june1966.

[8] Konikov nadya, Bleisch virgh, piskie violette, prognostic significance of cytologic diagnosis of effusion, Acta cytology 10(5): 335-339,oct 1966.
[9] Broghamer WL,Richardson ME,Faurest SE; Malignancy associated serosanguinous pleural effusion, Acta cytology- 28 (1) : 46-50,feb.1984.

[10] Liu K, Dodge K, Glassgow BJ et al, comparison of smears, cytospin and cell block preparations in diagnostic and cost effectiveness, Diagn cytopatol,19(1)july $1998 ; 70-4$. 